\title{
Investigating the properties of high-pressure-treated, reduced-sodium, low-moisture, part-skim Mozzarella cheese during refrigerated storage
}

\author{
M. Ozturk, ${ }^{* 1}$ S. Govindasamy-Lucey, $\dagger^{2}$ J. J. Jaeggi, $†$ M. E. Johnson, $†$ and J. A. Lucey† \\ *Department of Food Science, and \\ †Center for Dairy Research, University of Wisconsin, Madison 53706
}

\begin{abstract}
We proposed that the performance and sensory properties of reduced-Na, low-moisture, part-skim (LMPS) Mozzarella cheese could be extended by the application of high hydrostatic pressure (HHP) to cheese postmanufacture and thereby decrease microbial and enzymatic activity. Fermentation-produced camel chymosin was also used as a coagulant to help reduce proteolysis during storage. Average composition of the LMPS Mozzarella cheeses was $48.6 \pm 0.6 \%$ moisture, $22.5 \pm$ $0.4 \%$ fat, $24.5 \pm 0.6 \%$ protein, and $1.0 \pm 0.1 \% \mathrm{NaCl}$. Blocks of cheeses were divided into 3 groups randomly after manufacture and stored at approximately $4^{\circ} \mathrm{C}$ for 20 wk. The control group was not HHP treated. Two weeks after manufacture, 2 groups of cheese samples were treated with HHP at 500 or $600 \mathrm{MPa}$ for $3 \mathrm{~min}$ and then returned to storage at approximately $4^{\circ} \mathrm{C}$. Analysis was performed during $20 \mathrm{wk}$ of storage after cheese manufacture. Texture profile analysis (TPA) and dynamic low-amplitude oscillatory rheology were used to monitor cheese functionality. Quantitative descriptive analysis was conducted with 9 trained panelists using a 15-point scale to evaluate texture and flavor attributes of unmelted cheese as well as cheeses melted on pizzas. Pressure treatments at 500 and $600 \mathrm{MPa}$ resulted in approximately 1 and $2 \log$ reduction in the numbers of starter culture, respectively, compared with the control when measured $1 \mathrm{~d}$ after HHP treatment. Starter numbers continued to decrease in all cheeses over the $20 \mathrm{wk}$ of storage, but the decrease was larger in the HHP-treated cheeses. Even though the initial numbers of nonstarter lactic acid bacteria were the same in all cheeses, the numbers of these bacteria increased faster in the control cheeses. High-pressure treatment of LMPS Mozzarella cheese resulted in an initial (1 d after
\end{abstract}

\footnotetext{
Received January 8, 2018.

Accepted March 27, 2018

${ }^{1}$ Current address: College of Engineering, Department of Food Engineering, Sakarya University, Sakarya, Turkey.

${ }^{2}$ Corresponding author: rani@cdr.wisc.edu
}

HHP treatment) increase in $\mathrm{pH}$, but by 2 wk after HHP treatment there was no statistical difference in $\mathrm{pH}$ values between control and HHP-treated samples. Immediately after treatment, HHP-treated cheeses exhibited significantly lower TPA and sensory (unmelted) hardness. However, by 14 wk after pressure treatment, the 600-MPa HHP-treated cheese had significantly higher TPA compared with control or 500-MPa HHP-treated cheeses. Sensory panels also indicated that by $14 \mathrm{wk}$ after HHP treatment, the $600-\mathrm{MPa}$ treated samples were significantly firmer than the control or 500-MPa treated cheeses. Compared with control cheese, cheeses treated at 600 or $500 \mathrm{MPa}$ exhibited lower water-soluble nitrogen values at 6 and $10 \mathrm{wk}$ after pressure treatment, respectively. By 10 wh after pressure treatment, the levels of intact $\alpha_{S_{1}}$-casein were significantly higher in all HHP-treated cheeses compared with the control. Pizza sensory panels indicated that $600-\mathrm{MPa}$ treated cheese was significantly chewier and exhibited lower blister quantity and higher strand thickness compared with control cheeses. High hydrostatic pressure treatment of low-Na, LMPS Mozzarella cheese could result in the extension of its desired baking characteristics when the cheese is stored at refrigerated temperature.

Key words: high pressure, reduced sodium, camel chymosin, Mozzarella

\section{INTRODUCTION}

Low-moisture, part-skim (LMPS) Mozzarella cheese is mostly consumed as an ingredient on pizza. Desired performance properties of traditional LMPS Mozzarella cheese are acceptable (optimal) for only a relatively short time period (e.g., 3-4 wk) when stored under refrigeration conditions $\left(\sim 4^{\circ} \mathrm{C}\right.$; Kindstedt, 1993). During longer storage, cheese becomes soft and pasty due to casein hydrolysis. Aged cheese becomes excessively fluid when melted. Heat treatment during the cooking and stretching process decreases, but does not eliminate, residual chymosin activity during cheese storage. High cooking temperatures result in higher levels of intact $\alpha_{\mathrm{S} 1}-\mathrm{CN}$ in cheese during ripening (Feeney et al., 
2002; Lucey et al., 2003). Previous studies suggested that cheese firmness and stretchability were related to the level of intact $\alpha_{\mathrm{S} 1}$-CN (Creamer, 1976; De Jong, 1976). Moynihan et al. (2014) investigated the effect of fermentation-produced bovine and camel chymosin on LMPS Mozzarella cheese functionality. They reported that cheeses manufactured with camel chymosin exhibited reduced levels of primary proteolysis compared with cheeses manufactured with calf chymosin. Cheeses made with camel chymosin also maintained desirable unmelted and melted characteristics during $84 \mathrm{~d}$ of refrigerated storage.

Several other methods have been investigated to improve performance shelf life of Mozzarella cheese. Bertola et al. (1996) reported that the viscoelastic and sensory properties of Mozzarella cheese could be maintained using frozen storage, although not all researchers agree that freezing produces high-quality cheese (Dahlstrom, 1978; Oberg et al., 1992). Cervantes et al. (1983) reported that the freezing-thawing cycle was a critical parameter affecting the quality of frozen LMPS Mozzarella during storage. However, frozen storage results in extra costs for cheese manufacturers, such as investment in freezing equipment, maintenance costs, and-most important - energy costs. Some manufacturers use individual quick freezing technology for pizza cheese to prevent deterioration of the cheese properties during storage.

High hydrostatic pressure (HHP) processing has become popular in the food industry to extend product shelf life and quality. The number of commercial HHP units has dramatically increased over the past $20 \mathrm{yr}$; correspondingly, the cost of HHP has become more feasible for industrial processing of foods and beverages (Bermúdez-Aguirre and Barbosa-Cánovas, 2011). Textural, rheological, and sensory characteristics of cheeses can be modified with HHP depending on the magnitude of the pressure or holding time treatment (Malone et al., 2003; Ozturk et al., 2013a). Malone et al. (2003) reported that the activity of major glycolytic and proteolytic enzymes (including residual chymosin) was reduced or inhibited with pressures $\geq 500 \mathrm{MPa}$, suggesting that HHP could be useful tool to arrest cheese ripening. For example, Evert-Arriagada et al. (2014) reported that 500-MPa HHP treatment of starter-free fresh cheese increased shelf life from 7 to $8 \mathrm{~d}$ to 19 to $21 \mathrm{~d}$.

There is a current trend in the food industry to reduce sodium in processed foods (Johnson et al., 2009); some overseas markets also prefer reduced-sodium cheeses. Salt $(\mathrm{NaCl})$ influences the conformation of caseins, final moisture content of cheese, hydration of protein network, as well as microbial and enzymatic activity in cheese (Cervantes et al., 1983; Guinee, 2004). Grant
(2011) reported that decreasing the $\mathrm{NaCl}$ content of Cheddar cheese caused quality defects, such as soft and pasty texture, lower meltability, and development of off-flavor. These types of defects could be a major quality problem for reduced-Na LMPS Mozzarella cheese, where shredability, meltability, and a clean background flavor are important attributes for its end use (i.e., pizza).

Low-moisture, part-skim Mozzarella cheese generally requires a short aging period at refrigeration temperature $\left(4^{\circ} \mathrm{C}\right)$ to attain the desired melt and stretch characteristics when baked on a pizza. Solubilization of $\mathrm{Ca}$ associated with the casein in cheese occurs during this time, which results in the physical changes necessary for LMPS Mozzarella cheese to attain the desired machinability and bake characteristics (Johnson and Lucey, 2006). After the desired characteristics are reached, minimizing biochemical changes in the cheese matrix may help extend the shelf life of LMPS Mozzarella cheese. Therefore, we hypothesized that reduced-Na LMPS Mozzarella cheese could be stored at refrigeration temperature $\left(4^{\circ} \mathrm{C}\right)$ without loss in quality attributes for more than the normal period of 4 to $6 \mathrm{wk}$ if these cheeses were HHP treated at pressures $\geq 500$ $\mathrm{MPa}$ for $3 \mathrm{~min}$.

\section{MATERIALS AND METHODS}

\section{Cheese Manufacture}

Two licensed Wisconsin cheese makers manufactured 5 batches of reduced-Na LMPS Mozzarella cheeses at the University of Wisconsin-Madison Dairy Plant over a period of 5 wk. Milk was received at the dairy plant $1 \mathrm{~d}$ before cheese manufacture. On each manufacturing date, 3 batches of cheese were made in cheese vats sized to hold $272 \mathrm{~kg}$ of milk to obtain the required amount of cheese curd. All 3 batches were manufactured with the same make procedure, starter, rennet, and milk supply. Partially skimmed $(2.55 \pm 0.05 \%$ fat $)$ milk was pasteurized at $73^{\circ} \mathrm{C}$ for $19 \mathrm{~s}$, cooled to $33.3^{\circ} \mathrm{C}$, and inoculated with a direct-vat-set thermophilic culture (a blend of Streptococcus thermophilus and Lactobacillus helveticus; Tempo 303, DSM Food Specialties Cultures USA Inc., Waukesha, WI) at a rate of $23 \mathrm{~g} / 272 \mathrm{~kg}$ of milk. Fermentation-produced camel chymosin (Chymax M, Chr. Hansen, Milwaukee, WI) was added to the milk at a rate of $10 \mathrm{~g} / 272 \mathrm{~kg}$ of milk 45 min after starter addition. The coagula were cut on firmness (subjectively evaluated by the cheesemaker; $\mathrm{pH} \sim 6.5$ ) with $1.9-\mathrm{cm}$ knives about 45 min after chymosin was added. After cutting, the curd was given a 10-min heal time (no stirring), and then the curd and whey were stirred as the temperature of the vats was increased to $41^{\circ} \mathrm{C}$ over 
a 30-min period. Whey was drained once the curd $\mathrm{pH}$ reached 5.9. Curd was matted and the mat was cut into smaller slabs and cheddared. At $\mathrm{pH} 5.2$, the slabs were milled and presalted at a rate of $210 \mathrm{~g}$ of salt/ vat. Curds were stretched in a cooker (Supreme Filata Mixer, Stainless Steel Fabricating Inc., Columbus, WI) containing water maintained at $71^{\circ} \mathrm{C}$ with a total residence time of approximately $8 \mathrm{~min}$. After the hot curd $\left(\sim 58^{\circ} \mathrm{C}\right)$ exited the cooker, it was placed in rectangular molds $(9 \times 9 \times 27 \mathrm{~cm})$. Cheese blocks $(2.3 \mathrm{~kg})$ were cooled in a water bath $\left(\sim 9^{\circ} \mathrm{C}\right)$ for $1 \mathrm{~h}$ before brine salting $\left[25 \%\right.$ (wt/wt) salt brine at $\mathrm{pH} 5.2$ held at $4^{\circ} \mathrm{C}$ for 45 min]. After brine salting, blocks were vacuum packed, randomly separated into 3 groups, and stored at $4^{\circ} \mathrm{C}$ during a 20-wk period. One group of blocks was not high pressure treated, whereas the other 2 sets of blocks were. Analysis was performed at 2, 4, 6, 8, 12, 16, and 20 wk of storage.

\section{HHP Treatment}

Blocks were HHP treated 2 wk after cheese manufacture. We wanted to allow some time for salt equilibration and fermentation of any residual lactose. For each HHP condition (500 or $600 \mathrm{MPa}$ for $3 \mathrm{~min}$ ), 10 blocks of cheese were used. A commercial high-pressure unit (Avure Ultra 215 L, Avure Technologies Inc., Middletown, $\mathrm{OH}$ ) located at American Pasteurization Company (Milwaukee, WI) was used for this study; the capacity of the HHP unit was $215 \mathrm{~L}(\sim 150 \mathrm{~kg}$, depending on the product size and packaging) of product per cycle. This high-pressure unit used water as the pressure transfer medium. The pressure come-up time was around 2 and $3 \mathrm{~min}$ for $500-$ and $600-\mathrm{MPa}$ treatments, respectively. During the compression cycle, the temperature of the water in the holding tank increased from about 5.4 to $7.4^{\circ} \mathrm{C}$. The decompression cycle took about $30 \mathrm{~s}$. Ten blocks of cheese were nonpressurized and kept as a control for each trial.

\section{Compositional Analyses}

Milk was analyzed for protein (total percentage $\mathrm{N}$ $\times$ 6.38, Kjeldahl method; AOAC International, 2000), casein (AOAC International, 2000), fat (Mojonnier method; AOAC International, 2000), lactose (AOAC International, 2000), TS (Green and Park, 1980), total Ca by inductively coupled argon plasma emission spectroscopy (Vista-MPX Simultaneous ICP-OES, Varian Inc., Palo Alto, CA; Park, 2000), and insoluble Ca phosphate by the acid-base titration method (Lucey et al., 1993; Hassan et al., 2004). The rennet whey was prepared as described in Lucey et al. (1993) and then analyzed for soluble Ca content.
To minimize potential compositional differences within a cheese block, blocks were sampled by cutting them lengthwise into 2 equal halves. One half was used for sensory analysis, and the other half was used to evaluate textural properties and cheese composition (performed at 2 wk after cheese manufacture). Cheeses were analyzed for protein by the Kjeldahl method (AOAC International, 2000); fat (Mojonnier method; AOAC International, 2000), moisture (Marshall, 1992), and salt by the chloride electrode method (model 926; Corning Glass Works, Medfield, MA; Johnson and Olson, 1985); and lactose, galactose, and lactic acid using HPLC method (Zeppa et al., 2001). The pH values were measured during ripening by directly inserting a spear tip pH probe (accuCap Capillary Junction $\mathrm{pH}$ combination electrode 13-620-133; Fisher Scientific, Itasca, IL) into the cheese block. The insoluble Ca content in cheeses was monitored until 12 wk of storage by the acid-base titration method (Lucey et al., 1993; Hassan et al., 2004). Total Ca and Na were determined by inductively coupled argon plasma emission spectroscopy (Vista-MPX Simultaneous ICP-OES, Varian Inc.; Park, 2000). All analyses were carried out in triplicate.

\section{Microbiological Analysis}

Starter and nonstarter lactic acid bacteria (NSLAB) numbers were measured by de Man, Rogosa and Sharpe agar and Rogosa SL medium, respectively. Plates were incubated at $32^{\circ} \mathrm{C}$ for $48 \mathrm{~h}$ under anaerobic conditions (Frank and Yousef, 2004; Ozturk et al., 2013b).

\section{Proteolysis and Urea PAGE Gels}

Water-soluble nitrogen levels were used to monitor cheese proteolysis (AOAC International, 2000). UreaPAGE was used to monitor hydrolysis of $\alpha_{S^{-}}$and $\beta-C N$ hydrolysis during storage. Preparation of urea-PAGE gels was previously described (Ozturk et al., 2013b). Gel images were analyzed and protein bands were quantified using image analysis software (Gel Expert 3.5; Nucleo Tech, San Carlos, CA).

\section{Rheological and Textural Measurements}

Rheological properties of the cheese samples were measured by dynamic small amplitude oscillatory rheology as described by Ozturk et al. (2013a). Temperature sweep test (from 5 to $85^{\circ} \mathrm{C}$ at a heating rate of $1^{\circ} \mathrm{C} / \mathrm{min}$ ) was used with a frequency of $0.08 \mathrm{~Hz}$ and a strain of $0.5 \%$ to measure the storage modulus $\left(\mathbf{G}^{\prime}\right)$, loss modulus $\left(\mathbf{G}^{\prime \prime}\right)$, and loss tangent ( $\mathbf{L T}$, which is the ratio between the viscous and the elastic properties of the material; $\mathrm{LT}=\mathrm{G}^{\prime \prime} / \mathrm{G}^{\prime}$ ) values. The maximum $\mathrm{LT}$ 
value observed during heating was also recorded. We also calculated the temperature where $\mathrm{LT}=1$ (i.e., where $G^{\prime \prime}=G^{\prime}$ ), as this indicates the transition from a solid to a liquid-like system (i.e., a crossover point), or the melting point. Texture profile analysis (TPA) tests were carried out using a TA.XT2 Texture Analyzer (Texture Technologies Corp., Scarsdale, NY) as described by Ozturk et al. (2013a).

\section{Confocal Laser Scanning Microscopy}

Cheese samples were prepared for confocal laser scanning microscopy as described by Ozturk et al. (2013a). Cheese samples were cut from the center of the cheese block parallel to the fibrous network of the cheese in the direction of when the cheese curd exited the cooker in order to observe paracasein fibers.

\section{Descriptive Sensory Analysis}

Sensory texture and flavor properties of unmelted cheese cubes and melted cheese shreds (on baked pizza) were monitored as described by Moynihan et al. (2014). A mixture of sensory Spectrum and quantitative descriptive analysis (Meilgaard et al., 1999) were used to evaluate the sensory properties of cheeses by $\geq 9$ trained ( $>20 \mathrm{~h}$ of training) panelists. Cheese cubes were tempered at $11^{\circ} \mathrm{C}$ and evaluated for texture (firmness and cohesiveness of mass) and flavor (acid, salt, bitter, buttery) using a 15-point scale. All sensory panels were conducted in duplicate on 2 different days.

Cheeses were mechanically shredded using a commercial shredder (Urschel CC-D, Urschel Laboratories Inc., Chesterton, IN). Pizzas were prepared as described by Moynihan et al. (2014), where a 30.5-cm frozen pizza crust (Arrezzio Thin and Crisp Par-Baked, Sysco Food Services, Baraboo, WI) was thawed and $30 \mathrm{~g}$ of tomatobased pizza sauce (Contadina Roma-style tomatoes pizza sauce, Metcalfe's Market, Madison, WI) was spread over the crust. Approximately $300 \mathrm{~g}$ of mechanically shredded cheese was placed on the pizza crust and baked in a forced-air commercial oven (Impinger Ovens, Lincoln Foodservice Products Inc., Fort Wayne, IN) at $260^{\circ} \mathrm{C}$ for $5 \mathrm{~min}$ as described by Moynihan et al. (2014). The surface characteristics of melted cheese (free oil release, blister color, blister quantity, and skinning), stretch characteristics (strand length and strand thickness of stretched cheese), texture (hardness, chewiness, and cohesiveness of mass), and flavor attributes (acid, salt, bitter, and buttery) were evaluated as described by Moynihan et al. (2014). Photographs of cheese attributes at the different reference points were also available to the panelists.

\section{Experimental Design and Statistical Analyses}

Five replicate trials of reduced-Na LMPS Mozzarella cheeses were manufactured. In each trial, 3 batches (vats) of cheeses were made. Cheeses from all vats were randomized and separated into 3 groups after manufacture. Two of these 3 groups of cheese were HHP treated at either 500 or $600 \mathrm{MPa}$ for $3 \mathrm{~min}$, and 1 group was kept as a control. A $3 \times 5$ completely randomized block design that incorporated all 3 treatments (control, $500 \mathrm{MPa}, 600 \mathrm{MPa}$ ) and 5 cheesemaking days was used for analysis of the response variables relating to cheese composition. An ANOVA was carried out using the PROC GLM procedure of SAS (version 9.1; SAS Institute Inc., Cary, NC; SAS Institute, 2004). Duncan's multiple comparisons test was used to evaluate differences in the treatments at a significance level of $P$ $<0.05$ for cheese composition only.

The effect of the treatments and storage time as well as their interactions on $\mathrm{pH}$, starter culture numbers, NSLAB numbers, insoluble Ca, proteolysis, rheological, textural and functional properties were monitored using a split-plot design. In the whole-plot factor, cheesemaking day was the blocking factor and treatment was analyzed as a discontinuous variable. For the subplot factor, storage time and interaction of storage time and treatment were treated as variables. The interactive term of treatment and cheesemaking day was treated as the error term for the treatment effect. The ANOVA for the split-plot design was carried out using PROC GLM of SAS. Fisher's least significant difference test was carried out to evaluate differences in the treatment means at a significance level of $P<0.05$. Pearson correlation coefficients were estimated between various responses.

\section{RESULTS AND DISCUSSION}

\section{Cheese Composition and Acid-Base Buffering Curves}

The average composition of all the cheeses was 48.6 $\pm 0.6 \%$ moisture, $22.5 \pm 0.4 \%$ fat, $24.5 \pm 0.6 \%$ protein, and $1.0 \pm 0.1 \%$ salt. There were no significant $(P>$ $0.05)$ differences in galactose or lactic acid contents of the cheeses (results not shown). No residual lactose was detected by 2 wk of storage. Cheeses were HHP treated at 2 wk of age; thus, the residual lactose has already been depleted in the cheeses before HHP treatment. The $\mathrm{pH}$ values of cheeses were significantly $(P<0.05)$ influenced by HHP treatment (Table 1); $\mathrm{pH}$ of the cheeses $1 \mathrm{~d}$ after HHP treatment was $5.23 \pm 0.03,5.33$ \pm 0.03 , and $5.34 \pm 0.01$ for control, $500 \mathrm{MPa}$, and 600 $\mathrm{MPa}$ cheeses, respectively. However, by another 2 wk 
after HHP treatment, all cheeses exhibited similar $\mathrm{pH}$ values $(5.28 \pm 0.02)$. An immediate increase in cheese $\mathrm{pH}$ with HHP treatment is in agreement with previous reports (Johnston and Darcy, 2000; Rynne et al., 2008; Ozturk et al., 2013a). In our cheese samples, residual lactose was already depleted before the application of HHP. Insoluble Ca phosphate is a major type of buffer in cheese and milk (Lucey and Fox, 1993). Solubilization of insoluble Ca phosphate ions releases phosphate ions that associate with hydrogen ions (i.e., buffering; Johnson and Lucey, 2006). We believe that rapid solubilization of insoluble Ca occurs during HHP treatment (Figure 1), which explained the immediate increase in $\mathrm{pH}$ values of cheese. Slow solubilization of insoluble Ca phosphate in the control cheese during ripening (Figure 1) allows its $\mathrm{pH}$ to eventually increase (buffer up) to the same $\mathrm{pH}$ value as the HHP-treated cheeses. Desobry-Banon et al. (1994) reported that HHP up to $200 \mathrm{MPa}$ resulted in a slight decrease in the levels of insoluble Ca in milk. Huppertz and de Kruif (2007) used a different approach to investigate the effect of HHP on insoluble Ca of milk; they modified micelles by cross-linking caseins with transglutaminase. Pressure treatment solubilized insoluble Ca linearly with increasing pressure from 100 to $400 \mathrm{MPa}$. This may partially explain why Messens et al. (1998) and Ozturk et al. (2013b) did not observe significant changes in the level of insoluble $\mathrm{Ca}$ after the application of approximately $400 \mathrm{MPa}$. Cheese is a much concentrated system (protein/salt) than a milk solution; thus, HHP treatments higher than $400 \mathrm{MPa}$ might be required to solubilize significant levels of insoluble $\mathrm{Ca}$ in cheese. In this study, cheeses were HHP treated at 500 and $600 \mathrm{MPa}$, resulting in an immediate and significant $(P$ $<0.05)$ change in the levels of insoluble Ca. During storage, the levels of insoluble Ca did not significantly $(P>0.05)$ change for 500- and 600-MPa HHP-treated cheeses (Figure 1). However, during storage the levels of insoluble Ca decreased for control cheese (as expected) to reach similar levels as the 500- and 600-MPa HHPtreated cheeses by 6 wk of storage (Figure 1 ).

\section{Microbiology}

Pressure treatment at $600 \mathrm{MPa}$ for $3 \mathrm{~min}$ is often used in the food industry to pasteurize (cause up to a 5 log bacterial reduction) some types of food products or beverages. The HHP treatment did significantly reduce starter numbers (Table 1). However, in this study the treatment of cheeses at $600 \mathrm{MPa}$ for 3 min resulted in an only approximately $2 \log$ reduction in starter culture numbers (Table 2). The degree of reduction in starter culture numbers with HHP depends on the specific bacterial strain, cheese type, and cheese composition in

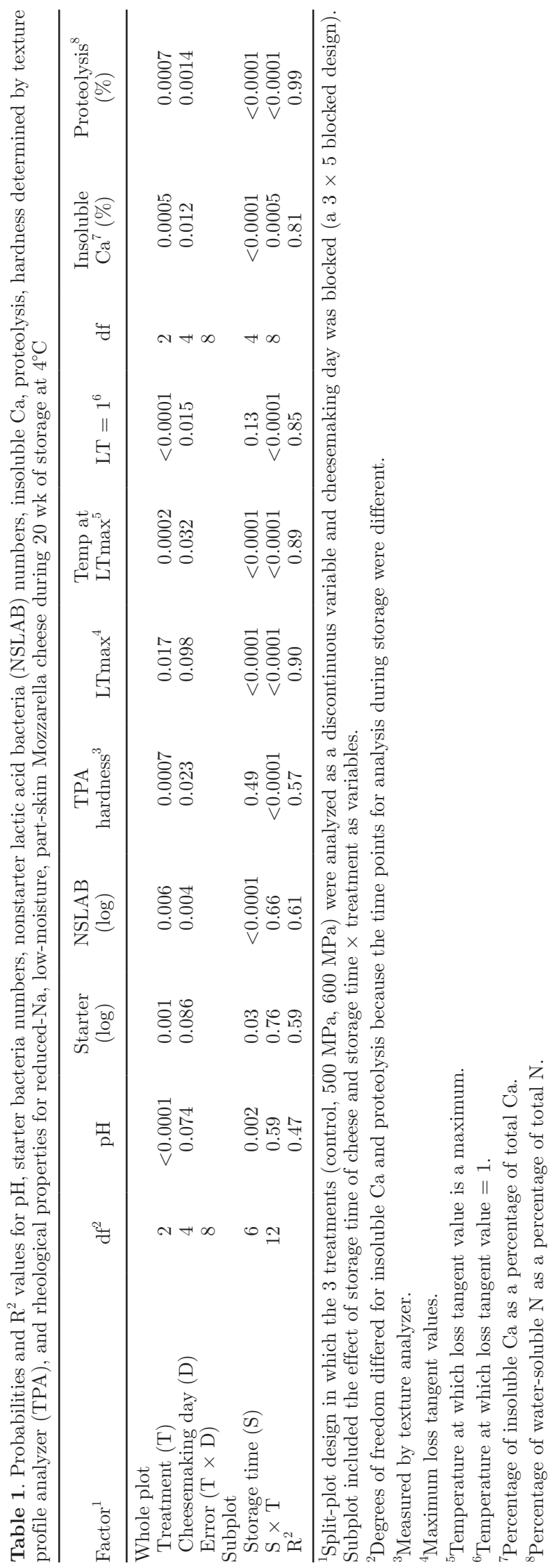

Journal of Dairy Science Vol. 101 No. 8, 2018 


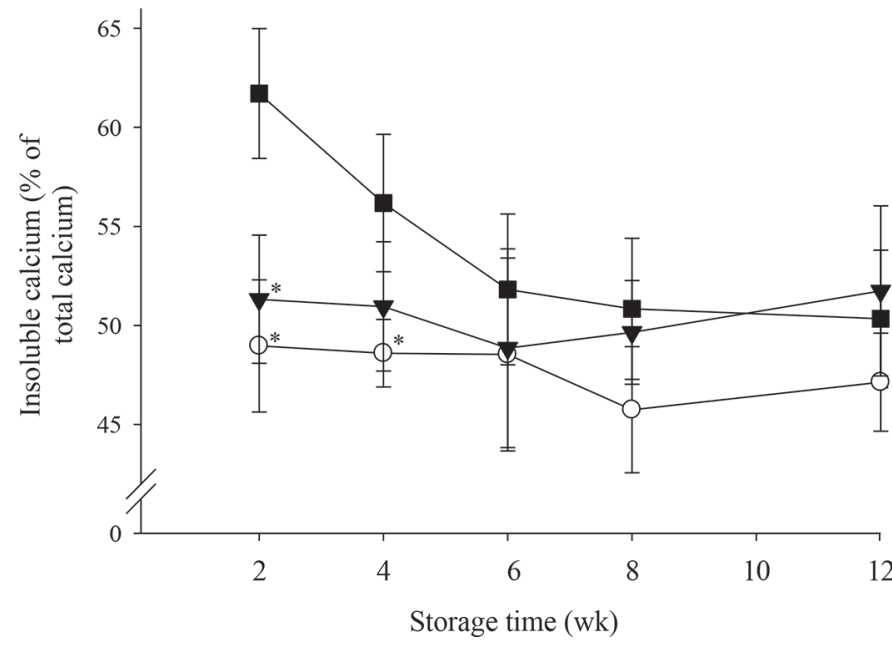

Figure 1. Insoluble $\mathrm{Ca}$, expressed as a percentage of total $\mathrm{Ca}$, for reduced-Na, low-moisture, part-skim Mozzarella cheeses during 12 wk of storage at $4^{\circ} \mathrm{C}$ for control cheese $(\boldsymbol{\square})$ or cheeses that were high hydrostatic pressure treated at $500 \mathrm{MPa}(\mathrm{O})$ and $600 \mathrm{MPa}(\boldsymbol{\nabla})$. Vertical bars represent standard deviations. An asterisk $(*)$ indicates significant $(P<0.05)$ difference from control cheese at the indicated storage time point.

addition to the magnitude of the HHP treatment and holding time (Rynne et al., 2008; Moschopoulou et al., 2010; Ozturk et al., 2013b). During storage, the starter numbers in the $600-\mathrm{MPa}$ treated cheeses continued to exhibit a large decrease (possibly reflecting loss of viability due to damage to the bacteria caused by the HPP treatment) as well as a lack of any residual lactose in the cheese (Table 2).

The NSLAB numbers were $<10 \mathrm{cfu} / \mathrm{g}$ in all cheeses at 2 wk of age (Table 2). Growth of NSLAB numbers was significantly slower in HHP treated cheeses (Table 1). At 6 and 8 wk of ripening, control cheese had significantly $(P<0.05)$ higher numbers of NSLAB compared with $600-\mathrm{MPa}$ treated cheese (Table 2); however, there was no significant difference in NSLAB numbers among all samples after $12 \mathrm{wk}$ of storage. However, after $20 \mathrm{wk}$ of storage, there was significantly less NSLAB in the 600-MPa HPP treated cheeses. Ozturk et al. (2013a) reported that HHP treatment between 50 and $225 \mathrm{MPa}$ initially slowed the development of NSLAB up to 1 mo of ripening in reduced-fat Cheddar cheese, but NSLAB numbers steadily decreased during ripening with the application of HHP $\geq 350 \mathrm{MPa}$. Even though the HHP conditions used in this study were higher than those in Ozturk et al. (2013a), we did not observe a reduction in NSLAB numbers immediately after HPP treatment. This may be due to the lower initial NSLAB numbers in our cheeses compared with Ozturk et al. (2013a) or to the effect of procedures such as curd heating used in the manufacture of Mozzarella compared with the Cheddar cheese studied by Ozturk et al. (2013a).

\section{Proteolysis}

The 600- and 500-MPa HHP cheeses exhibited significantly $(P<0.05)$ lower water-soluble $\mathrm{N}$ values compared with control cheese (Table 1) starting from $8 \mathrm{wk}$ and $12 \mathrm{wk}$ of storage, respectively (Figure 2). The water-soluble $\mathrm{N}$ levels in cheese are often used as an indicator of residual coagulant activity (Rank et al., 1985). There are conflicting results on the effect of HHP on overall proteolysis in cheese; researchers have reported reduced (Saldo et al., 2002), increased

Table 2. Starter and nonstarter lactic acid bacteria (NSLAB) numbers ${ }^{1}$ for control and 500- and 600-MPa HHP-treated, ${ }^{2}$ reduced-Na, low-moisture, part-skim Mozzarella cheeses during 20 wk of storage at $4^{\circ} \mathrm{C}$

\begin{tabular}{llccc}
\hline & & \multicolumn{3}{c}{ Treatment } \\
\cline { 2 - 4 } Attribute & $\begin{array}{l}\text { Storage } \\
\text { time (wk) }\end{array}$ & Control & $500 \mathrm{MPa}$ & $600 \mathrm{MPa}$ \\
\hline Starter $(\log )$ & 2 & $7.05^{\mathrm{a}}$ & $6.13^{\mathrm{ab}}$ & $5.23^{\mathrm{b}}$ \\
& 4 & $6.41^{\mathrm{a}}$ & $6.05^{\mathrm{a}}$ & $5.31^{\mathrm{a}}$ \\
& 6 & $6.35^{\mathrm{a}}$ & $5.82^{\mathrm{ab}}$ & $4.82^{\mathrm{b}}$ \\
& 8 & $6.44^{\mathrm{a}}$ & $5.62^{\mathrm{ab}}$ & $4.77^{\mathrm{b}}$ \\
& 12 & $6.58^{\mathrm{a}}$ & $5.25^{\mathrm{a}}$ & $4.50^{\mathrm{a}}$ \\
& 16 & $6.68^{\mathrm{a}}$ & $5.12^{\mathrm{a}}$ & $5.07^{\mathrm{a}}$ \\
& 20 & $6.51^{\mathrm{a}}$ & $4.39^{\mathrm{ab}}$ & $3.40^{\mathrm{b}}$ \\
& 2 & $0.70^{\mathrm{a}}$ & $0.70^{\mathrm{a}}$ & $0.70^{\mathrm{a}}$ \\
& 4 & $4.78^{\mathrm{a}}$ & $3.33^{\mathrm{a}}$ & $2.87^{\mathrm{a}}$ \\
& 6 & $5.57^{\mathrm{a}}$ & $3.89^{\mathrm{ab}}$ & $2.87^{\mathrm{b}}$ \\
& 8 & $5.51^{\mathrm{a}}$ & $2.84^{\mathrm{b}}$ & $2.27^{\mathrm{b}}$ \\
& 12 & $3.99^{\mathrm{a}}$ & $3.76^{\mathrm{a}}$ & $4.09^{\mathrm{a}}$ \\
& 16 & $5.31^{\mathrm{a}}$ & $5.10^{\mathrm{a}}$ & $5.00^{\mathrm{a}}$ \\
& 20 & $4.78^{\mathrm{a}}$ & $3.51^{\mathrm{a}}$ & $2.67^{\mathrm{b}}$ \\
\hline
\end{tabular}

$\overline{\mathrm{a}, \mathrm{b}}$ Means within a row with different superscripts differ $(P<0.05)$.

${ }^{1}$ Values are means $(\mathrm{n}=5)$. All values presented are in log numbers.

${ }^{2} \mathrm{HHP}=$ high hydrostatic pressure; 500 or $600 \mathrm{MPa}$ for 3 min at $6.4 \pm 1^{\circ} \mathrm{C}$ at 2 wk of cheese age. 


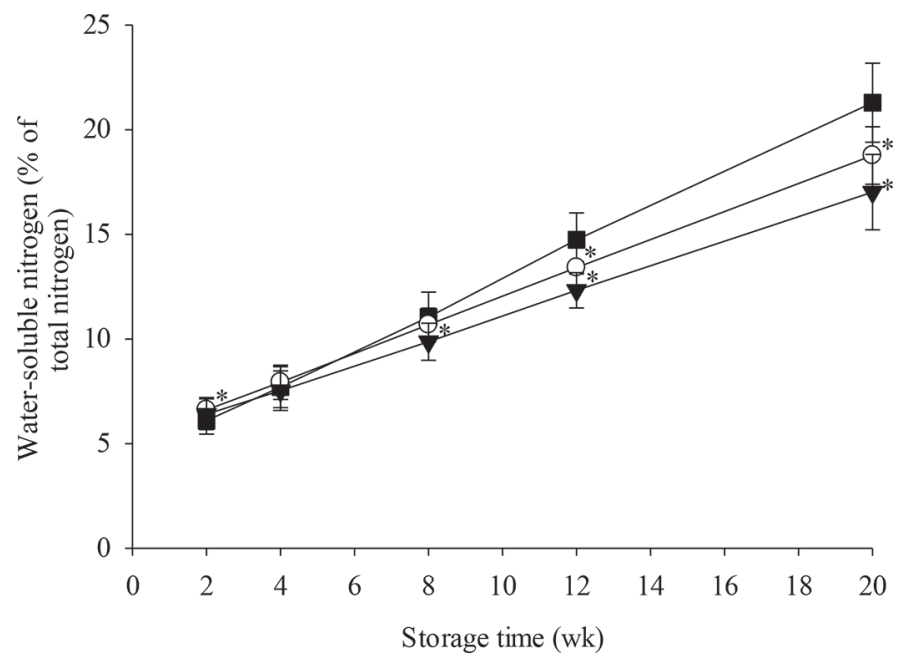

Figure 2. Water-soluble $\mathrm{N}$ as a percentage of total $\mathrm{N}$ values for reduced-Na, low-moisture, part-skim Mozzarella cheeses during $20 \mathrm{wk}$ of storage at $4^{\circ} \mathrm{C}$ for control cheese $(\mathbf{\square})$ or cheeses that were high hydrostatic pressure treated at $500 \mathrm{MPa}(\mathrm{O})$ and $600 \mathrm{MPa}(\boldsymbol{\nabla})$. Vertical bars represent standard deviations. An asterisk $(*)$ indicates significant $(P<0.05)$ difference from control cheese at the indicated storage time point.

(Saldo et al., 2000; Messens et al., 2001; O'Reilly et al., 2003), or unchanged (O'Reilly et al., 2002; Sheehan et al., 2005) levels of proteolysis in various cheese types following HHP treatment in the region of $400 \mathrm{MPa}$. Several factors seem to be important: composition of the cheese, the age of cheese when HHP was applied, the magnitude of HHP, and holding time. Low HHP treatments (e.g., $50 \mathrm{MPa}$ ) have been used to attempt to increase proteolysis (Yokohama et al., 1992; O'Reilly et al., 2000). Water-soluble $\mathrm{N}$ levels significantly increased with age in all cheeses (Table 1) as expected. At $2 \mathrm{wk}$ of age, we did not observe any major differences in the breakdown of caseins as monitored by urea-PAGE (Figure 3). Densitometric analysis of the urea-PAGE electrophoretograms revealed that degradation of $\alpha_{\mathrm{S}^{-}}$ CN was significantly $(P<0.05)$ lower after $12 \mathrm{wk}$ for the 500- and 600-MPa treated cheeses compared with the control (Figure 4). After 12 wk of storage, intact $\alpha_{\mathrm{S} 1}$-CN was significantly $(P<0.05)$ higher in $600-\mathrm{MPa}$ treated cheese than 500-MPa treated cheese in agreement with the trends from the water-soluble $\mathrm{N}$ analysis (Figure 2). Malone et al. (2003) reported that the activity of the major proteolytic enzymes in cheese (residual bovine chymosin and bacterial proteases, such as cell envelope protease, X-prolyl-dipeptidyl aminopeptidase, and aminopeptidase $\mathrm{N}$ ) decreased or was inactivated at HHP levels $\geq 500 \mathrm{MPa}$.

\section{Rheological Properties}

Rheological properties of reduced-Na LMPS Mozzarella cheeses were significantly $(P<0.05)$ affected by HHP treatment (Table 1$)$. The crossover tempera-

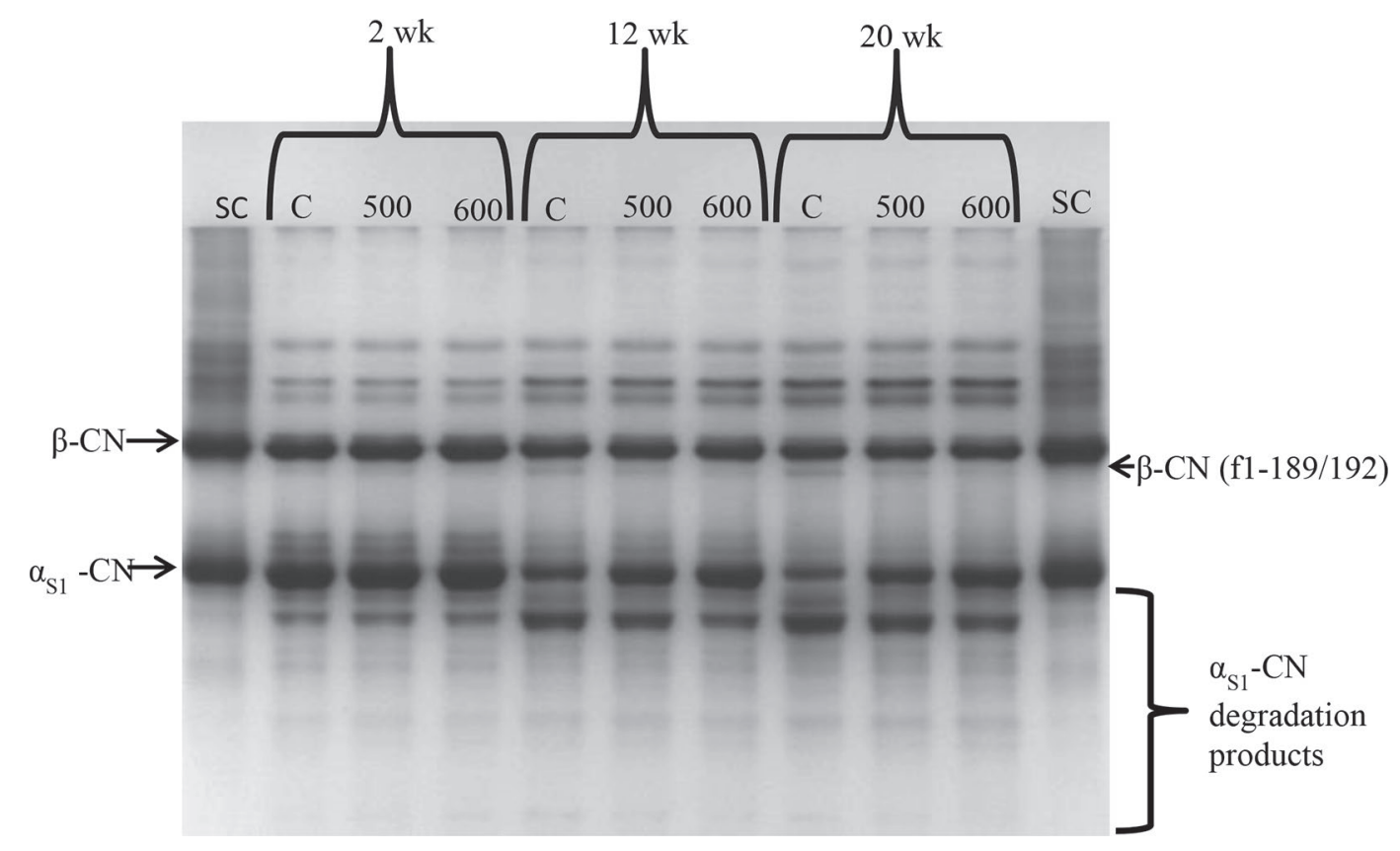

Figure 3. Urea-PAGE electrophoretograms showing the breakdown of caseins for reduced-Na, low-moisture, part-skim Mozzarella cheeses for control cheese (C) or cheeses that were high hydrostatic pressure treated at $500 \mathrm{MPa}(500)$ and $600 \mathrm{MPa}(600)$ at 2,12 , and 20 wk of storage at $4^{\circ} \mathrm{C}$. Lanes with $\mathrm{SC}$ refer to sodium caseinate (standards). 


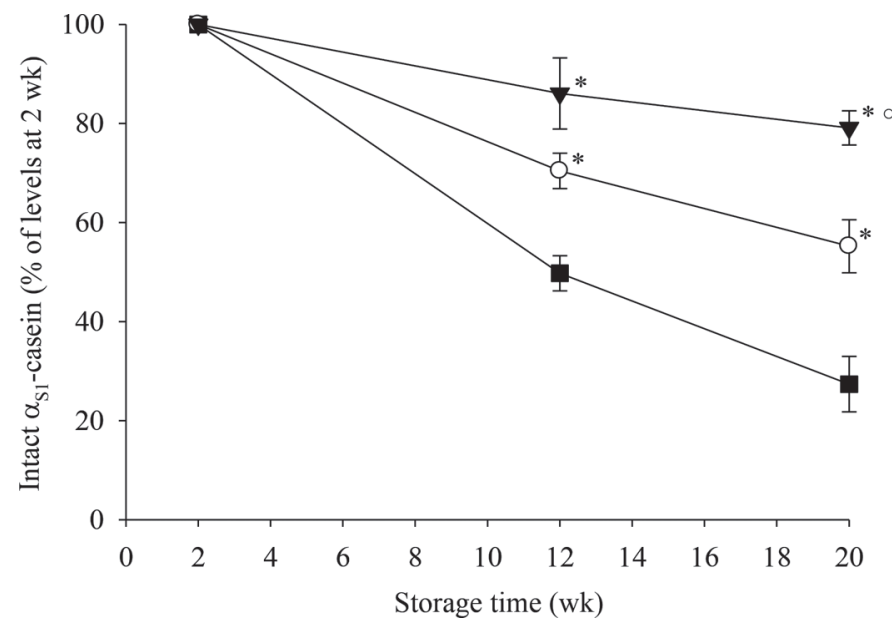

Figure 4. Level of intact $\alpha_{\mathrm{S}^{1}} \mathrm{CN}$ as a percentage of the level at 2 wk calculated from area (pixel intensity) by the Gel Expert program (Nucleo Tech, San Carlos, CA) from the urea-polyacrylamide gels for reduced-Na, low-moisture, part-skim Mozzarella cheeses during 20 wk of storage at $4^{\circ} \mathrm{C}$ for control cheeses ( $\left.\mathbf{\square}\right)$ or cheeses that were high hydrostatic pressure treated at $500 \mathrm{MPa}(\mathrm{O})$ and $600 \mathrm{MPa}(\mathbf{\nabla})$. Vertical bars represent standard deviations. An asterisk $(*)$ indicates significant $(P<0.05)$ difference from control cheese at the indicated ripening time point. A circle $\left(^{\circ}\right)$ indicates significant $(P<0.05)$ difference from cheese that was $500-\mathrm{MPa}$ treated at the indicated ripening time point.

ture $(\mathrm{LT}=1)$, which is an indicator of the melting temperature, was significantly lower for HHP-treated cheese compared with the control cheese immediately after HHP treatment, and the crossover temperature

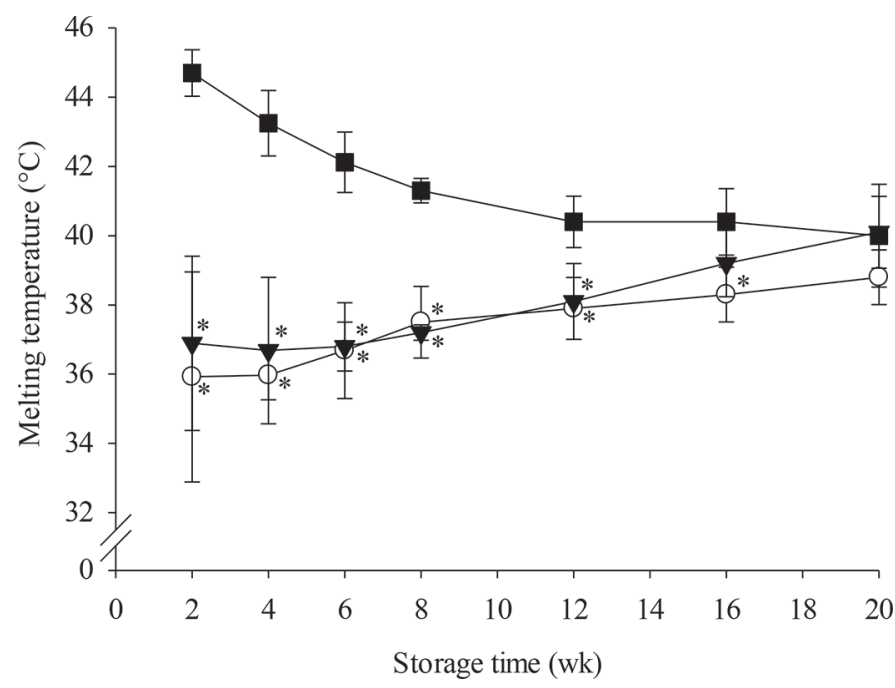

Figure 5. Temperature of the crossover point (where loss tangent $=1$ ) for reduced-Na, low-moisture, part-skim Mozzarella cheeses during 20 wk of storage at $4^{\circ} \mathrm{C}$ for control cheese $(\boldsymbol{\square})$ or cheeses that were high hydrostatic pressure treated at $500 \mathrm{MPa}(\mathrm{O})$ and $600 \mathrm{MPa}(\boldsymbol{\nabla})$. Vertical bars represent standard deviations. An asterisk (*) indicates significant $(P<0.05)$ difference from control cheese at the indicated storage time point. remained lower than the control until $20 \mathrm{wk}$ of storage (Figure 5). The decrease in melting temperature for the HHP-treated cheeses could be partially explained to be the result of the significantly lower insoluble $\mathrm{Ca}$ levels observed in the HHP-treated cheeses (Figure 1). Loss of insoluble Ca phosphate crosslinking between caseins increases their cheese meltability (Lucey et al., 2003). Proteolysis is another factor that affects melting temperature of cheeses (Lucey et al., 2003). During ripening, the higher water-soluble $\mathrm{N}$ levels (Figure 2) and faster rate of degradation of $\mathrm{a}_{\mathrm{S} 1}-\mathrm{CN}$ (Figure 4) probably caused the decrease in the melt temperature for the control cheeses (Figure 5). Messens et al. (2000) reported that HHP treatment of $400 \mathrm{MPa}$ disrupted hydrophobic interactions in Gouda cheese. The lower melting temperature of the HHP-treated cheeses could be a result of both their low insoluble $\mathrm{Ca}$ levels and decreased hydrophobic interactions between caseins. Melting temperature of control cheese decreased during storage as expected, whereas the melting temperatures of the HHP-treated cheeses did not change during storage. At 20 wk of storage, all cheeses exhibited similar melting temperature (Figure 5).

\section{Textural Properties}

The HHP treatment significantly affected TPA hardness (Table 1). During the initial stage of cheese storage, HHP-treated cheeses exhibited significantly $(P<$ 0.05) lower TPA hardness values compared with control cheese (Figure 6). Reduction in cheese hardness with HHP treatment has been previously reported (Messens et al., 2000; Ozturk et al., 2013a). Softening of HHPtreated cheeses could be due to greater solubilization of insoluble $\mathrm{Ca}$ (Figure 1) caused by the HHP process. Messens et al. (2000) and Ozturk et al. (2013a) also suggested that the reduction in cheese hardness with HHP treatment could be related to weaker (disrupted) hydrophobic interactions. The hardness of the control cheeses decreased significantly during ripening, whereas there was little change in hardness during storage with the HHP-treated cheeses (Figure 6). The slower rate of proteolysis in the HHP-treated cheeses likely contributed to maintaining higher hardness values. Intact $\alpha_{\mathrm{S} 1}$ CN levels were higher at $20 \mathrm{wk}$ in the $600-\mathrm{MPa}$ treated cheese compared with control or $500-\mathrm{MPa}$ treated cheese (Figure 4). De Jong (1976) reported that cheese hardness was closely related to the levels of intact $\alpha_{\mathrm{S}^{-}} \mathrm{CN}$.

\section{Confocal Laser Scanning Microscopy}

Confocal laser scanning microscopy images demonstrated that the number and the size of fat droplets and 
void spaces (channels) decreased with HHP treatment of cheeses (Figure 7). O'Reilly et al. (2002) reported that low-moisture Mozzarella cheese HHP treated at $400 \mathrm{MPa}$ resulted in the protein matrix in cheese becoming more continuous, and the fat was more visibly dispersed, in agreement with our results. Johnston and Darcy (2000) investigated the effect of HHP on the microstructure of 1-d-old fresh Mozzarella cheese using scanning electron microscopy. They reported that void spaces disappeared after HHP treatment, whereas serum-fat channels were clearly visible in control cheese. Johnston and Darcy (2000) and O'Reilly et al. (2002) also reported that the HHP treatment of Mozzarella cheese accelerated the normal storage-related microstructural changes to the cheese matrix. Our results showed that at 4 wk of storage, there were less obvious differences in the microstructures between control and HHP-treated cheeses (due to ripening reactions in the control cheese). The HHP-treated cheese exhibited little change in the microstructure with storage (e.g., Figure 7c and $\mathrm{f}$ ) in contrast to the control cheese (Figure $7 \mathrm{a}$ and $\mathrm{d})$.

\section{Sensory Analysis: Unmelted Cheese}

High-pressure treatment influenced the unmelted sensory firmness and cohesiveness (degree to which the cheese holds together as a mass) of the cheeses (Table 3). Pressure treatment at $500 \mathrm{MPa}$ initially decreased

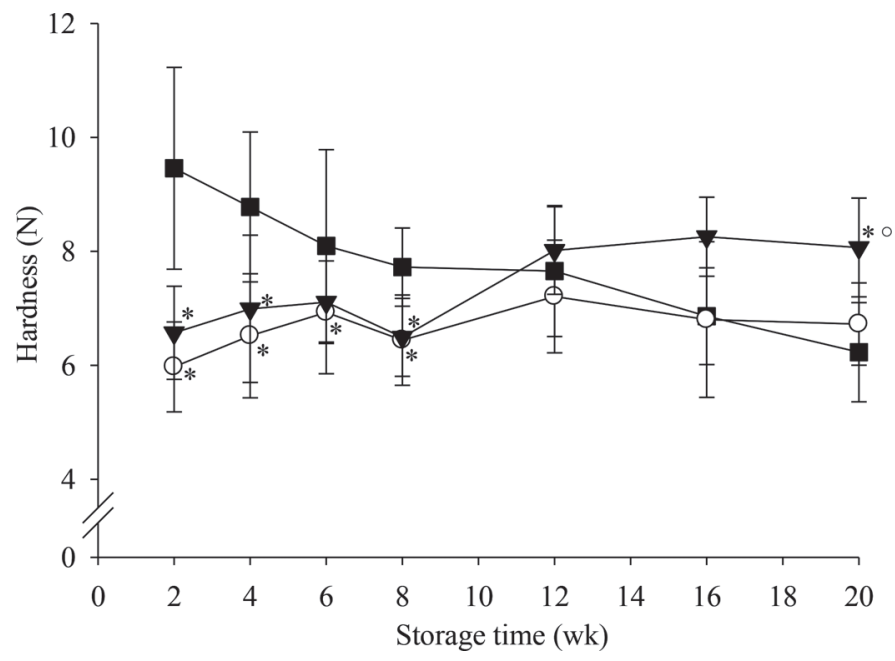

Figure 6. Hardness (N) from texture profile analysis testing $(20 \%$ compression of cheese cylinders compared with original height) for reduced-Na, low-moisture, part-skim Mozzarella cheeses during $20 \mathrm{wk}$ of storage at $4^{\circ} \mathrm{C}$ for control cheese ( $)$ or cheeses that were high hydrostatic pressure treated at $500 \mathrm{MPa}(\mathrm{O})$ and $600 \mathrm{MPa}(\boldsymbol{\nabla})$. Vertical bars represent standard deviations. An asterisk $(*)$ indicates significant $(P<0.05)$ difference from control cheese at the indicated storage time point. A circle $\left(^{\circ}\right)$ indicates significant $(P<0.05)$ difference from cheese that was 500-MPa treated at the indicated ripening time point. sensory firmness and increased the cohesiveness compared with the control cheese (Table 4). At 8 wk of storage, there was no significant difference in the sensory firmness of the control or HHP-treated cheeses. There was no significant change in firmness or cohesiveness of the $600-\mathrm{MPa}$ treated cheese with storage (Table 4). From 12 wk of storage onward, the $600-\mathrm{MPa}$ treated cheese was firmer than the control. Generally, the sensory firmness results of all the cheese were in agreement with the TPA hardness results (Figure 6). There is a general trend that as cheeses become softer they also become more cohesive (Foegeding and Drake, 2007). There was no major difference in buttery attribute between cheeses during aging, except at 4 and 8 wk of storage. All cheeses received very low bitterness scores ( $<1$ on a 15 -point scale) during 20 wk of storage (results not shown). Recent studies have reported that cheeses manufactured with camel chymosin exhibited lower bitterness scores compared with cheeses manufactured with calf chymosin (Govindasamy-Lucey et al., 2010; Grant, 2011; Möller et al., 2013).

\section{Sensory Analysis: Melted Cheese}

Shredded cheese was baked on pizza crust (covered with tomato sauce) to evaluate the melted cheese characteristics (surface color and appearance, stretch, texture, and flavor). Blister color, formation of free oil, and skinning were not influenced by HHP treatment during storage (results not shown). The HHP treatment did significantly affect melted properties such as blister quantity, strand thickness, strand length, and hardness (Table 3). Blister quantity increased in control cheeses with age but did not change in HHP-treated cheeses (Table 4). After 8 wk of storage, HHP-treated cheeses had significantly $(P<0.05)$ lower blister quantity (Table 4). Oberg et al. (1991) reduced proteolytic activity in Mozzarella cheeses by using proteinase-deficient starter cultures, and these cheeses exhibited less browning (as measured by a reflectance colorimeter). Reduction in the proteolytic activity in HHP-treated cheeses likely explains the lower blister quantity in cheeses during storage. Peptides and AA generated from proteolysis could increase blister color via the Maillard reaction.

Stretch quality of cheese was analyzed sensorially by measuring strand length and thickness. Stretch can be described as the ability of the continuous casein network in hot cheese to maintain its integrity under an applied elongational stress (Lucey et al., 2003). All young cheeses exhibited similar $(P>0.05)$ strand thickness and length (Table 4). During storage, the $600-\mathrm{MPa}$ treated cheese sample exhibited significantly $(P<0.05)$ higher strand length and thickness compared with the control (Table 4). Lucey et al. (2003) 

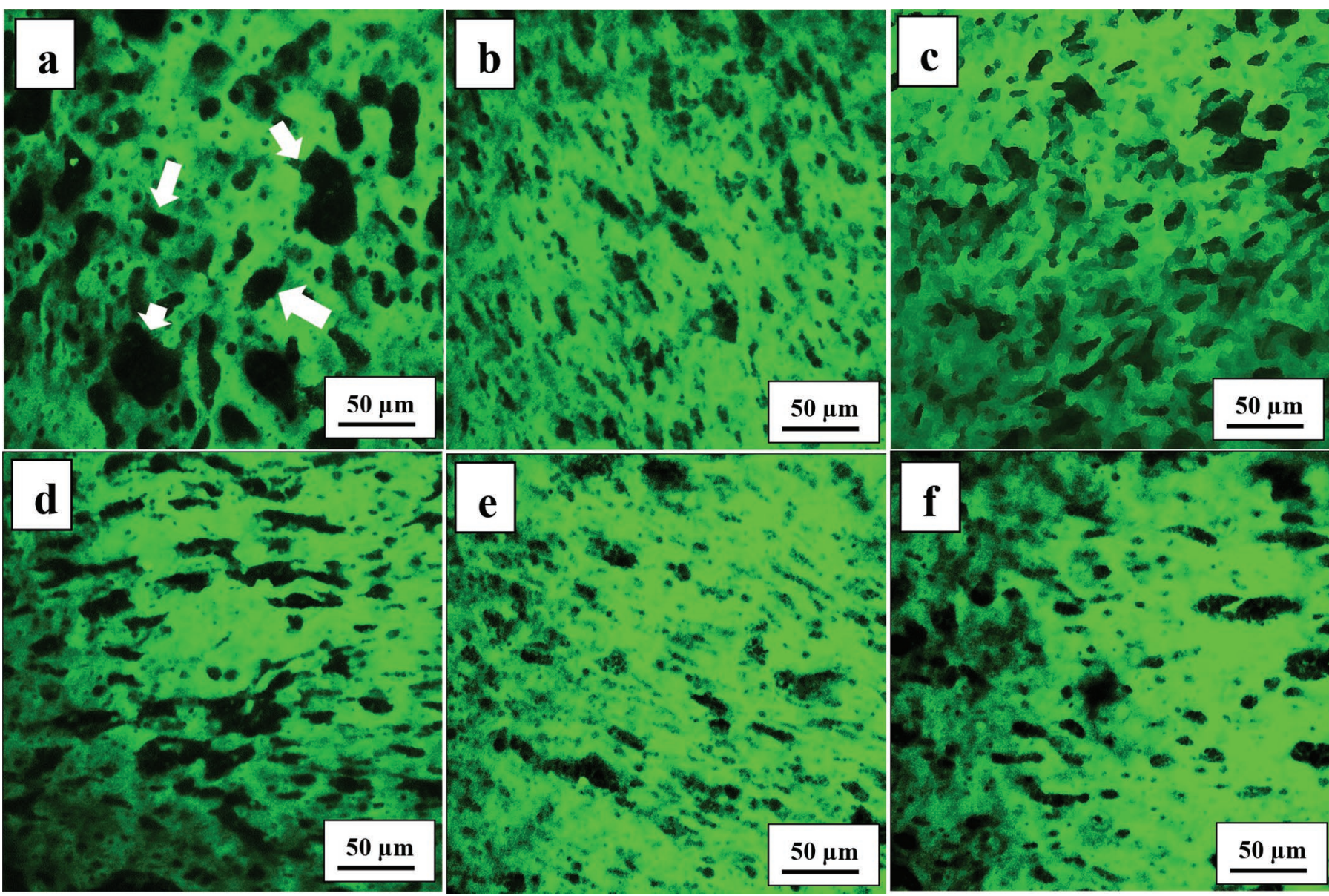

Figure 7. Confocal laser scanning micrographs showing fat droplets or void spaces as dark areas (pointed out with arrows) against a light (green) background (protein) for reduced-Na, low-moisture, part-skim Mozzarella cheeses for control cheese (a, d) or cheeses that were high hydrostatic pressure (HHP) treated at $500 \mathrm{MPa}(\mathrm{b}, \mathrm{e})$ and $600 \mathrm{MPa}(\mathrm{c}, \mathrm{f})$ at 2 wk (immediately after HPP treatment) and 4 wk of storage at $4^{\circ} \mathrm{C}$, respectively.

reported that stretch decreases during cheese ripening due to hydrolysis of the protein network, resulting in a discontinuous casein network (or small breaks or weak spots in the casein strands). Oberg et al. (1991) reported that cheeses made with proteinase-deficient cultures retained more stretch during storage of LMPS

Table 3. Probabilities and $\mathrm{R}^{2}$ values for sensorial properties of unmelted reduced-Na, low-moisture, part-skim Mozzarella cheese and cheeses that were melted on pizzas in a forced-air commercial oven ${ }^{1}$

\begin{tabular}{|c|c|c|c|c|c|c|c|c|c|}
\hline Factor $^{2}$ & df & \multicolumn{3}{|c|}{ Unmelted cheese } & \multicolumn{5}{|c|}{ Melted cheese } \\
\hline Treatment $(\mathrm{T})$ & 2 & $<0.001$ & 0.004 & 0.005 & 0.009 & $<0.0001$ & $<0.01$ & $<0.001$ & $<0.01$ \\
\hline Cheesemaking day (D) & 4 & 0.0002 & 0.0003 & 0.005 & 0.37 & 0.19 & 0.65 & 0.004 & 0.12 \\
\hline Error $(\mathrm{T} \times \mathrm{D})$ & 8 & & & & & & & & \\
\hline $\mathrm{S} \times \mathrm{T}$ & 10 & 0.28 & $<0.001$ & 0.67 & $<0.0001$ & $<0.01$ & $<0.0001$ & 0.57 & 0.31 \\
\hline $\mathrm{R}^{2}$ & & 0.59 & 0.72 & 0.72 & 0.68 & 0.83 & 0.74 & 0.68 & 0.77 \\
\hline
\end{tabular}

${ }^{1}$ Cheeses were assessed during $20 \mathrm{wk}$ of storage at $4{ }^{\circ} \mathrm{C}$.

${ }^{2}$ Split-plot design in which the 3 treatments (control, $500 \mathrm{MPa}, 600 \mathrm{MPa}$ ) were analyzed as a discontinuous variable and cheesemaking day was blocked (a $3 \times 5$ blocked design). Subplot included the effect of storage time of cheese and storage time $\times$ treatment as variables.

${ }^{3}$ Strand lengths (how far the cheese elongates before it breaks) were reported in centimeters. 
Table 4. Sensory analysis results for control and 500- and 600-MPa HHP-treated, ${ }^{1}$ reduced-Na, low-moisture, part-skim Mozzarella cheeses that were tested as unmelted at $4^{\circ} \mathrm{C}$ and melted on pizza in a forced-air commercial oven ${ }^{2}$

\begin{tabular}{|c|c|c|c|c|}
\hline \multirow[b]{2}{*}{ Attribute } & \multirow{2}{*}{$\begin{array}{l}\text { Storage } \\
\text { time (wk) }\end{array}$} & \multicolumn{3}{|c|}{ Treatment } \\
\hline & & Control & $500 \mathrm{MPa}$ & $600 \mathrm{MPa}$ \\
\hline \multicolumn{5}{|l|}{ Unmelted } \\
\hline \multirow{6}{*}{ Firmness } & 2 & $8.6^{\mathrm{a}, \mathrm{A}}$ & $7.6^{\mathrm{b}, \mathrm{A}}$ & $7.9^{\mathrm{ab}, \mathrm{A}}$ \\
\hline & 4 & $8.6^{\mathrm{a}, \mathrm{A}}$ & $7.3^{\mathrm{b}, \mathrm{A}}$ & $8.1^{\mathrm{ab}, \mathrm{A}}$ \\
\hline & 8 & $8.1^{\mathrm{a}, \mathrm{AB}}$ & $8.0^{\mathrm{a}, \mathrm{A}}$ & $8.4^{\mathrm{a}, \mathrm{A}}$ \\
\hline & 12 & $7.2^{\mathrm{b}, \mathrm{B}}$ & $6.6^{\mathrm{b}, \mathrm{A}}$ & $7.9^{\mathrm{a}, \mathrm{A}}$ \\
\hline & 16 & $6.9^{\mathrm{b}, \mathrm{B}}$ & $7.1^{\mathrm{b}, \mathrm{A}}$ & $7.9^{\mathrm{a}, \mathrm{A}}$ \\
\hline & 20 & $7.4^{\mathrm{b}, \mathrm{B}}$ & $7.3^{\mathrm{b}, \mathrm{A}}$ & $8.1^{\mathrm{a}, \mathrm{A}}$ \\
\hline \multirow[t]{6}{*}{ Cohesiveness } & 2 & $8.5^{\mathrm{b}, \mathrm{C}}$ & $9.9^{\mathrm{a}, \mathrm{A}}$ & $9.8^{\mathrm{a}, \mathrm{A}}$ \\
\hline & 4 & $9.3^{\mathrm{b}, \mathrm{B}}$ & $10.5^{\mathrm{a}, \mathrm{A}}$ & $10.2^{\mathrm{a}, \mathrm{A}}$ \\
\hline & 8 & $10.3^{\mathrm{a}, \mathrm{A}}$ & $10.5^{\mathrm{a}, \mathrm{A}}$ & $10.0^{\mathrm{a}, \mathrm{A}}$ \\
\hline & 12 & $10.2^{\mathrm{a}, \mathrm{A}}$ & $10.3^{\mathrm{a}, \mathrm{A}}$ & $10.3^{\mathrm{a}, \mathrm{A}}$ \\
\hline & 16 & $10.7^{\mathrm{a}, \mathrm{A}}$ & $10.5^{\mathrm{a}, \mathrm{A}}$ & $10.0^{\mathrm{b}, \mathrm{A}}$ \\
\hline & 20 & $10.6^{\mathrm{a}, \mathrm{A}}$ & $10.6^{\mathrm{a}, \mathrm{A}}$ & $10.1^{\mathrm{b}, \mathrm{A}}$ \\
\hline \multirow[t]{6}{*}{ Buttery } & 2 & $3.9^{\mathrm{a}, \mathrm{BC}}$ & $4.1^{\mathrm{a}, \mathrm{A}}$ & $3.9^{\mathrm{a}, \mathrm{AB}}$ \\
\hline & 4 & $4.0^{\mathrm{a}, \mathrm{BC}}$ & $4.1^{\mathrm{a}, \mathrm{A}}$ & $3.7^{\mathrm{b}, \mathrm{BC}}$ \\
\hline & 8 & $4.2^{\mathrm{a}, \mathrm{AB}}$ & $4.1^{\mathrm{a}, \mathrm{A}}$ & $4.2^{\mathrm{a}, \mathrm{A}}$ \\
\hline & 12 & $4.4^{\mathrm{a}, \mathrm{A}}$ & $4.1^{\mathrm{ab}, \mathrm{A}}$ & $3.9^{\mathrm{b}, \mathrm{AB}}$ \\
\hline & 16 & $3.3^{\mathrm{a}, \mathrm{D}}$ & $3.3^{\mathrm{a}, \mathrm{B}}$ & $3.4^{\mathrm{a}, \mathrm{C}}$ \\
\hline & 20 & $3.6^{\mathrm{a}, \mathrm{D}}$ & $3.4^{\mathrm{a}, \mathrm{B}}$ & $3.3^{\mathrm{a}, \mathrm{C}}$ \\
\hline \multicolumn{5}{|l|}{ Melted } \\
\hline \multirow[t]{6}{*}{ Blister quantity } & 2 & $5.1^{\mathrm{a}, \mathrm{C}}$ & $6.0^{\mathrm{a}, \mathrm{A}}$ & $6.4^{\mathrm{a}, \mathrm{A}}$ \\
\hline & 4 & $5.6^{\mathrm{a}, \mathrm{BC}}$ & $5.9^{\mathrm{a}, \mathrm{A}}$ & $6.5^{\mathrm{a}, \mathrm{A}}$ \\
\hline & 8 & $6.7^{\mathrm{a}, \mathrm{B}}$ & $6.5^{\mathrm{a}, \mathrm{A}}$ & $6.4^{\mathrm{a}, \mathrm{A}}$ \\
\hline & 12 & $9.4^{\mathrm{a}, \mathrm{A}}$ & $7.3^{\mathrm{b}, \mathrm{A}}$ & $6.0^{\mathrm{b}, \mathrm{A}}$ \\
\hline & 16 & $9.6^{\mathrm{a}, \mathrm{A}}$ & $7.6^{\mathrm{b}, \mathrm{A}}$ & $5.7^{\mathrm{c}, \mathrm{A}}$ \\
\hline & 20 & $8.9^{\mathrm{a}, \mathrm{A}}$ & $7.7^{\mathrm{ab}, \mathrm{A}}$ & $6.7^{\mathrm{b}, \mathrm{A}}$ \\
\hline \multirow[t]{6}{*}{ Strand thickness } & 2 & $6.7^{\mathrm{a}, \mathrm{A}}$ & $7.0^{\mathrm{a}, \mathrm{A}}$ & $7.1^{\mathrm{a}, \mathrm{A}}$ \\
\hline & 4 & $6.7^{\mathrm{a}, \mathrm{A}}$ & $7.2^{\mathrm{a}, \mathrm{A}}$ & $6.8^{\mathrm{a}, \mathrm{A}}$ \\
\hline & 8 & $4.7^{\mathrm{b}, \mathrm{B}}$ & $5.3^{\mathrm{ab}, \mathrm{B}}$ & $6.3^{\mathrm{a}, \mathrm{A}}$ \\
\hline & 12 & $3.7^{\mathrm{b}, \mathrm{C}}$ & $4.4^{\mathrm{b}, \mathrm{B}}$ & $6.3^{\mathrm{a}, \mathrm{AB}}$ \\
\hline & 16 & $3.6^{\mathrm{b}, \mathrm{C}}$ & $4.0^{\mathrm{ab}, \mathrm{B}}$ & $5.2^{\mathrm{a}, \mathrm{BC}}$ \\
\hline & 20 & $1.3^{\mathrm{b}, \mathrm{D}}$ & $2.2^{\mathrm{b}, \mathrm{C}}$ & $5.0^{\mathrm{a}, \mathrm{C}}$ \\
\hline \multirow[t]{6}{*}{ Strand length ${ }^{3}$} & 2 & $45.2^{\mathrm{a}, \mathrm{A}}$ & $40.9^{\mathrm{ab}, \mathrm{A}}$ & $37.0^{\mathrm{b}, \mathrm{A}}$ \\
\hline & 4 & $39.4^{\mathrm{a}, \mathrm{AB}}$ & $39.1^{\mathrm{a}, \mathrm{A}}$ & $39.1^{\mathrm{a}, \mathrm{A}}$ \\
\hline & 8 & $36.6^{\mathrm{a}, \mathrm{B}}$ & $37.1^{\mathrm{a}, \mathrm{AB}}$ & $37.1^{\mathrm{a}, \mathrm{A}}$ \\
\hline & 12 & $26.4^{\mathrm{b}, \mathrm{C}}$ & $26.0^{\mathrm{b}, \mathrm{BC}}$ & $40.9^{\mathrm{a}, \mathrm{A}}$ \\
\hline & 16 & $23.9^{\mathrm{b}, \mathrm{C}}$ & $27.4^{\mathrm{b}, \mathrm{BC}}$ & $39.9^{\mathrm{a}, \mathrm{A}}$ \\
\hline & 20 & $13.8^{\mathrm{b}, \mathrm{D}}$ & $17.1^{\mathrm{b}, \mathrm{C}}$ & $38.3^{\mathrm{a}, \mathrm{A}}$ \\
\hline \multirow[t]{6}{*}{ Hardness } & 2 & $3.2^{\mathrm{a}, \mathrm{A}}$ & $2.9^{\mathrm{a}, \mathrm{AB}}$ & $3.2^{\mathrm{a}, \mathrm{A}}$ \\
\hline & 4 & $3.1^{\mathrm{a}, \mathrm{AB}}$ & $3.2^{\mathrm{a}, \mathrm{A}}$ & $3.2^{\mathrm{a}, \mathrm{A}}$ \\
\hline & 8 & $2.8^{\mathrm{a}, \mathrm{AB}}$ & $3.1^{\mathrm{a}, \mathrm{AB}}$ & $3.2^{\mathrm{a}, \mathrm{A}}$ \\
\hline & 12 & $3.1^{\mathrm{a}, \mathrm{AB}}$ & $3.2^{\mathrm{a}, \mathrm{A}}$ & $3.4^{\mathrm{a}, \mathrm{A}}$ \\
\hline & 16 & $2.6^{\mathrm{b}, \mathrm{B}}$ & $2.7^{\mathrm{b}, \mathrm{BC}}$ & $3.1^{\mathrm{a}, \mathrm{A}}$ \\
\hline & 20 & $2.0^{\mathrm{b}, \mathrm{C}}$ & $2.4^{\mathrm{a}, \mathrm{C}}$ & $2.7^{\mathrm{a}, \mathrm{B}}$ \\
\hline \multirow[t]{6}{*}{ Chewiness } & 2 & $7.2^{\mathrm{a}, \mathrm{A}}$ & $7.1^{\mathrm{a}, \mathrm{A}}$ & $7.1^{\mathrm{a}, \mathrm{A}}$ \\
\hline & 4 & $7.1^{\mathrm{a}, \mathrm{A}}$ & $6.9^{\mathrm{a}, \mathrm{A}}$ & $7.3^{\mathrm{a}, \mathrm{A}}$ \\
\hline & 8 & $6.3^{\mathrm{a}, \mathrm{B}}$ & $6.5^{\mathrm{a}, \mathrm{AB}}$ & $6.6^{\mathrm{a}, \mathrm{B}}$ \\
\hline & 12 & $6.1^{\mathrm{a}, \mathrm{B}}$ & $6.2^{\mathrm{a}, \mathrm{BC}}$ & $6.6^{\mathrm{a}, \mathrm{B}}$ \\
\hline & 16 & $5.6^{\mathrm{b}, \mathrm{C}}$ & $5.9^{\mathrm{b}, \mathrm{BC}}$ & $6.2^{\mathrm{a}, \mathrm{B}}$ \\
\hline & 20 & $5.2^{\mathrm{b}, \mathrm{C}}$ & $5.6^{\mathrm{b}, \mathrm{C}}$ & $6.3^{\mathrm{a}, \mathrm{B}}$ \\
\hline
\end{tabular}

${ }^{a-c}$ Means within a row with different lowercase superscripts differ $(P<0.05$; comparing the effect of treatment at a single storage time).

${ }^{\mathrm{A}-\mathrm{D}}$ Means within a column (for a particular attribute) with different uppercase superscripts $\operatorname{differ}(P<0.05$; comparing the effect of storage time at a single treatment).

${ }^{1} \mathrm{HHP}=$ high hydrostatic pressure; 500 or $600 \mathrm{MPa}$ for 3 min at $6.4 \pm 1^{\circ} \mathrm{C}$ at 2 wk of cheese age.

${ }^{2}$ Cheeses were assessed during 20 wk of storage at $4^{\circ} \mathrm{C}$.

${ }^{3}$ Strand lengths (how far the cheese elongates before it breaks) were reported in centimeters. 
Mozzarella. Thus, higher intact $\alpha_{\mathrm{S}^{-}} \mathrm{CN}$ levels (Figure 4) could be responsible for greater stretchability of 600$\mathrm{MPa}$ treated cheese compared with the control.

Pressure treatment did not significantly $(P>0.05)$ affect the acidity and bitterness of the melted cheeses (results not shown). The buttery flavor of melted cheese significantly $(P<0.05)$ increased with $600-\mathrm{MPa}$ treatment (results not shown).

Textural characteristics of melted cheese on pizza, such as hardness, chewiness (Table 3), and cohesiveness of mass (results not shown), were significantly $(P<$ $0.05)$ affected by HHP treatment. Hardness and chewiness of melted cheese were similar in all treatments up to $12 \mathrm{wk}$ of age, but during further storage the control cheese exhibited a significantly larger reduction in these attributes (Table 4). O'Reilly et al. (2002) reported that HHP treatment (400 MPa for $25 \mathrm{~min}$ ) of low-moisture Mozzarella cheese increased the water-holding capacity, enhanced swelling of the protein matrix, and improved cooking characteristics (e.g., flowability, fluidity, and stretchability). We also observed structural changes in the protein matrix of our cheeses with confocal laser scanning microscopy images that were similar to those found by O'Reilly et al. (2002), but we observed a decrease in the rate of proteolysis, which was possibly due to the higher pressure $(600 \mathrm{MPa})$ used in our study.

\section{CONCLUSIONS}

High-pressure treatments at $600 \mathrm{MPa}$ for $3 \mathrm{~min}$ significantly affected microbiology, texture, rheology, and pizza performance of reduced-Na LMPS Mozzarella cheese. Rheological and textural properties of the cheeses were initially altered by HHP treatment but then remained fairly unchanged during 20 wk of refrigerated storage. The results indicated that $600-\mathrm{MPa}$ treatment helped minimize typical age-related changes in the performance of the reduced-Na LMPS Mozzarella cheeses. The HHP treatment of cheese caused an immediate reduction in insoluble Ca levels in the cheeses, which coincided with lower hardness and melting temperatures, but they did not change further during the 20 -wk storage period. The rapid solubilization of $\mathrm{Ca}$ during the HHP treatment also explained the immediate increase in the $\mathrm{pH}$ of these cheeses. However, slow solubilization of Ca phosphate occurring in the control cheese during storage allowed the $\mathrm{pH}$ of the control cheese to eventually increase to the same $\mathrm{pH}$ value as the pressure-treated cheeses. The HHP treatment did slow down proteolysis with the application of higher pressure $(600 \mathrm{MPa})$. Reduction in the proteolytic activity in HHP-treated cheeses likely explains some of the changes in the performance of these cheeses on pizzas compared with the control cheeses, such as lower blister quantity and higher stretch quality. Thus, this study demonstrated that the performance shelf life of LMPS Mozzarella cheeses can be extended from the traditional 4 to 6 wk to $20 \mathrm{wk}$ of refrigerated storage by the application of HHP at $600 \mathrm{MPa}$ for $3 \mathrm{~min}$.

\section{ACKNOWLEDGMENTS}

The authors thank the Center for Dairy Research (Madison, WI) personnel for their assistance in cheese making, analytical work, and sensory analyses. We also thank American Pasteurization Company (Milwaukee, WI) for their help and support in the high-pressure processing of the cheeses. We also thank DSM Food Specialties Cultures USA Inc. (Waukesha, WI) and Chr. Hansen Inc. (Milwaukee, WI) for their donation of starter cultures and coagulants used in this study. The financial support of the Center for Dairy Research Cheese Industry Team is greatly appreciated. We also appreciate the support of the Dairy Farmers of Wisconsin (Madison, WI) and National Dairy Council (Rosemont, IL).

\section{REFERENCES}

AOAC International. 2000. Official Methods of Analysis. 17th ed. AOAC International, Arlington, VA.

Bermúdez-Aguirre, D., and G. Barbosa-Cánovas. 2011. An update on high hydrostatic pressure, from the laboratory to industrial applications. Food Eng. Rev. 3:44-61.

Bertola, N. C., A. N. Califano, A. E. Bevilacqua, and N. E. Zaritzky. 1996. Effect of freezing conditions on functional properties of low moisture Mozzarella cheese. J. Dairy Sci. 29:185-190.

Cervantes, M. A., D. B. Lund, and N. F. Olson. 1983. Effects of salt concentration and freezing on Mozzarella cheese texture. J. Dairy Sci. 66:204-213.

Creamer, L. K. 1976. Casein proteolysis in Mozzarella-type cheese. N.Z. J. Dairy Sci. Tech. 11:130-131.

Dahlstrom, D. G. 1978. Frozen storage of low moisture part skim Mozzarella cheese. MS Thesis. Department of Food Science, University of Wisconsin, Madison.

De Jong, L. 1976. Protein breakdown in soft cheese and its relation to consistency. I. Proteolysis and consistency of "Noordhollanse Meshanger" cheese. Neth. Milk Dairy J. 30:242-253.

Desobry-Banon, S., F. Richard, and J. Hardy. 1994. Study of acid and rennet coagulation of high pressurized milk. J. Dairy Sci. 77:3267-3274.

Evert-Arriagada, K., M. M. Hernández-Herrero, B. Guamis, and A. J. Trujillo. 2014. Commercial application of high-pressure processing for increasing starter-free fresh cheese shelf-life. Food Sci. Technol. 55:498-505.

Feeney, E. P., P. F. Fox, and T. P. Guinee. 2002. Effect of pH and calcium level on the proteolysis in Mozzarella cheese. J. Dairy Sci. $85: 1646-1654$

Foegeding, E. A., and M. A. Drake. 2007. Sensory and mechanical properties of cheese texture. J. Dairy Sci. 90:1611-1624.

Frank, J. F., and A. E. Yousef. 2004. Tests for groups of microorganisms. Pages 227-247 in Standard Methods for the Examination of Dairy Products. 17th ed. H. M. Wehr and J. F. Frank, ed. American Public Health Association, Washington, DC.

Govindasamy-Lucey, S., Y. Lu, J. J. Jaeggi, M. E. Johnson, and J. A. Lucey. 2010. Impact of camel chymosin on the texture and sen- 
sory properties of low-fat Cheddar cheese. Aust. J. Dairy Technol. 65:139-142.

Grant, K. V. 2011. Impact of sodium chloride reduction on the compositional, functional, and flavor properties of full-fat Cheddar cheese. MS Thesis. Department of Food Science, University of Wisconsin, Madison.

Green, W. C., and K. K. Park. 1980. Comparison of AOAC, microwave and vacuum oven methods for determining total solids in milk. J. Food Prot. 4:782-783.

Guinee, T. P. 2004. Salting and the role of salt in cheese. Int. J. Dairy Technol. 57:99-109.

Hassan, A., M. E. Johnson, and J. A. Lucey. 2004. Changes in the proportions of soluble and insoluble calcium during the ripening of Cheddar cheese. J. Dairy Sci. 87:854-862.

Huppertz, T., and C. G. de Kruif. 2007. High pressure-induced solubilisation of micellar calcium phosphate from cross-linked casein micelles. Colloids Surf. A Physicochem. Eng. Asp. 295:264-268.

Johnson, M. E., R. Kapoor, D. J. McMahon, D. R. McCoy, and R. G. Narasimmon. 2009. Reduction of sodium and fat levels in natural and processed cheeses: Scientific and technological aspects. Compr. Rev. Food Sci. Food Saf. 8:252-268.

Johnson, M. E., and J. A. Lucey. 2006. Calcium: A key factor in controlling cheese functionality. Aust. J. Dairy Technol. 61:147-153.

Johnson, M. E., and N. F. Olson. 1985. A comparison of available methods for determining salt levels in cheese. J. Dairy Sci. 68:1020-1024.

Johnston, D. E., and P. C. Darcy. 2000. The effects of high pressure treatment on immature mozzarella cheese. Milchwissenschaft $55: 617-620$.

Kindstedt, P. S. 1993. Mozzarella and pizza cheese. Pages 337-362 in Cheese: Chemistry, Physics and Microbiology. Vol. 2. 2nd ed. P. F. Fox, ed. Chapman and Hill, London, UK.

Lucey, J. A., and P. F. Fox. 1993. Importance of calcium and phosphate in cheese manufacture: A review. J. Dairy Sci. 76:1714-1724.

Lucey, J. A., B. Hauth, C. Gorry, and P. F. Fox. 1993. The acid-base buffering properties of milk. Milchwissenschaft 48:268-272.

Lucey, J. A., M. E. Johnson, and D. S. Horne. 2003. Perspectives on the basis of the rheology and texture properties of cheese. J. Dairy Sci. 86:2725-2743.

Malone, A. S., C. Wick, T. H. Shellhammer, and P. D. Courtney. 2003. High pressure effects on proteolytic and glycolytic enzymes involved in cheese manufacturing. J. Dairy Sci. 86:1139-1146.

Marshall, R. T. 1992. Standard Methods for the Examination of Dairy Products. 16th ed. American Public Health Association, Washington, DC.

Meilgaard, M. M., G. V. Civille, and B. T. Carr. 1999. Selection and training of panel members. Pages 174-176 in Sensory Evaluation Techniques. 3rd ed. CRC Press, Boca Raton, FL.

Messens, W., K. Dewettinck, J. Van Camp, and A. Huyghebaert. 1998. High pressure brining of Gouda cheese and its effect on the cheese serum. Lebensm. Wiss. Technol. 31:552-558.

Messens, W., I. Foubert, K. Dewettinck, and A. Huyghebaert. 2001. Proteolysis of a high-pressure-treated mould-ripened cheese. Milchwissenschaft 56:201-204.

Messens, W., D. Van de Walle, J. Arevalo, K. Dewettinck, and A. Huyghebaert. 2000. Rheological properties of high-pressure-treated Gouda cheese. Int. Dairy J. 10:359-367.

Möller, K. K., F. P. Rattray, and Y. Ardo. 2013. Application of selected lactic acid bacteria and coagulant for improving the quality of low-salt Cheddar cheese: Chemical, microbiological and rheological evaluation. Int. Dairy J. 33:163-174.
Moschopoulou, E., T. Anisa, G. Katsaros, P. Taoukis, and G. Moatsou. 2010. Application of high-pressure treatment on ovine brined cheese: Effect on composition and microflora throughout ripening. Innov. Food Sci. Emerg. Technol. 11:543-550.

Moynihan, A. C., S. Govindasamy-Lucey, J. J. Jaeggi, M. E. Johnson, J. A. Lucey, and P. L. H. McSweeney. 2014. Effect of camel chymosin on the texture, functionality, and sensory properties of low-moisture, part-skim Mozzarella cheese. J. Dairy Sci. 97:85-96.

O'Reilly, C. E., A. L. Kelly, J. C. Oliveira, P. M. Murphy, M. A. E. Auty, and T. P. Beresford. 2003. Effect of varying high-pressure treatment conditions on acceleration of ripening of Cheddar cheese. Innov. Food Sci. Emerg. Technol. 4:277-284.

O'Reilly, C. E., P. M. Murphy, A. L. Kelly, T. P. Guinee, M. A. E. Auty, and T. P. Beresford. 2002. The effect of high pressure treatment on the functional and rheological properties of Mozzarella cheese. Innov. Food Sci. Emerg. Technol. 3:3-9.

O'Reilly, C. E., P. M. O'Connor, P. M. Murphy, A. L. Kelly, and T. P. Beresford. 2000. The effect of exposure to pressure of $50 \mathrm{MPa}$ on Cheddar cheese ripening. Innov. Food Sci. Emerg. Technol. 1:109-117.

Oberg, C. J., R. K. Merrill, R. J. Brown, and G. H. Richardson. 1992. Effects of freezing, thawing, and shredding on low moisture, partskim Mozzarella cheese. J. Dairy Sci. 75:1161-1166.

Oberg, C. J., A. Wang, L. V. Moyes, R. J. Brown, and G. H. Richardson. 1991. Effects of proteolytic activity of thermolactic cultures on physical properties of Mozzarella cheese. J. Dairy Sci. 74:389-397.

Ozturk, M., S. Govindasamy-Lucey, J. J. Jaeggi, K. Houck, M. E. Johnson, and J. A. Lucey. 2013a. Impact of various high pressure treatments on the properties of reduced fat Cheddar cheese. J. Dairy Sci. 96:6792-6806.

Ozturk, M., S. Govindasamy-Lucey, J. J. Jaeggi, M. E. Johnson, and J. A. Lucey. 2013b. The influence of high hydrostatic pressure on regular, reduced, low and no salt added Cheddar cheese. Int. Dairy J. 33:175-183.

Park, Y. W. 2000. Comparison of mineral and cholesterol composition of different commercial goat milk products manufactured in USA. Small Rumin. Res. 37:115-124.

Rank, T. C., R. Grappin, and N. F. Olson. 1985. Secondary proteolysis of cheese during ripening: A review. J. Dairy Sci. 64:801-805.

Rynne, N. M., T. P. Beresford, T. P. Guinee, E. Sheehan, C. M. Delahunty, and A. L. Kelly. 2008. Effect of high-pressure treatment of 1 day-old full-fat Cheddar cheese on subsequent quality and ripening. Innov. Food Sci. Emerg. Technol. 9:429-440.

Saldo, J., P. L. H. McSweeney, E. Sendra, A. L. Kelly, and B. Guamis. 2000. Changes in curd acidification caused by high pressure treatment. Ir. J. Agric. Food Res. 39:169-173.

Saldo, J., P. L. H. McSweeney, E. Sendra, A. L. Kelly, and B. Guamis. 2002. Proteolysis in caprine milk cheese treated by high pressure to accelerate cheese ripening. Int. Dairy J. 12:35-44.

SAS Institute. 2004. SAS User's Guide: Statistics. Version 9.1. SAS Inst. Inc., Cary, NC.

Sheehan, J. J., T. Huppertz, M. G. Hayes, A. L. Kelly, T. P. Beresford, and T. P. Guinee. 2005. High pressure treatment of reduced-fat Mozzarella cheese: Effects on functional and rheological properties. Innov. Food Sci. Emerg. Technol. 6:73-81.

Yokohama, H., N. Sawamura, and N. Motobayashi. 1992. Method for accelerating cheese ripening. European Patent application EP, 469 857(0) A1. Fuji Oil Co. Ltd., assignee.

Zeppa, G., L. Conterno, and V. Gerbi. 2001. Determination of organic acids, sugars, diacetyl, and acetoin in cheese by high-performance liquid chromatography. J. Agric. Food Chem. 49:2722-2726. 